SJ Quinney College of Law, University of Utah

Utah Law Digital Commons

\title{
U.S. v. Clinesmith: Amicus Brief in Support of Motion for Relief Under The Crime Victims' Rights Act
}

Paul Cassell

James R. Marsh 


\section{UNITED STATES DISTRICT COURT FOR THE}

\section{THE DISTRICT OF COLUMBIA}

\begin{tabular}{ll} 
UNITED STATES OF AMERICA & ) \\
Plaintiff & ) \\
v. & ) \\
KEVIN CLINESMITH, & ) \\
Defendant & ) \\
& ) \\
\hline
\end{tabular}

BRIEF OF THE NATIONAL CRIME VICTIM LAW INSTITUTE, THE NATIONAL ORGANIZATION FOR VICTIM ASSISTANCE, THE NATIONAL CENTER FOR VICTIMS OF CRIME, ARIZONA VOICE FOR CRIME VICTIMS, THE NETWORK FOR VICTIM RECOVERY OF THE DISTRICT OF COLUMBIA, OHIO CRIME VICTIM JUSTICE CENTER, ROCKY MOUNTAIN VICTIM LAW CENTER, SOUTH CAROLINA VICTIM ASSISTANCE NETWORK, AND UTAH CRIME VICTIMS LEGAL CLINIC AS AMICI CURIAE IN SUPPORT OF MOTION FOR RELIEF UNDER THE CRIME VICTIMS' RIGHTS ACT

James R. Marsh

(Local Counsel)

DDC Bar ID 436448

MARSH LAW FIRM PLLC

31 Hudson Yards, 11th Floor

New York, NY 10001
Paul G. Cassell

(Counsel of Record)

S.J. QUINNEY COLLEGE OF LAW

University of Utah

383 S. University St.

Salt Lake City, UT 84112

(no institutional endorsement implied)

(pro hac vice application to be filed) 


\section{TABLE OF CONTENTS}

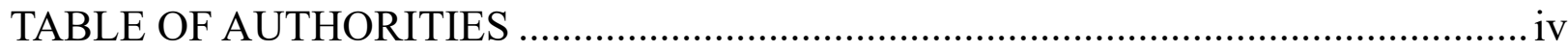

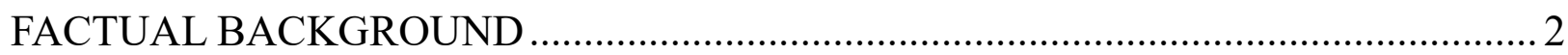

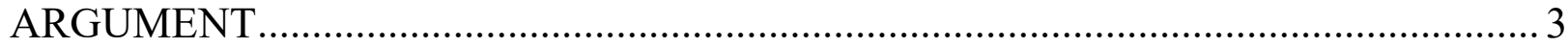

I. Under the CVRA, Dr. Page is a "Crime Victim" of the Defendant's Offense ........ 3

A. The CVRA Is a Broad Bill of Rights Protecting All "Victims" of Federal Crimes 3

B. To Be Recognized as a "Victim" of a Federal Crime, an Individual Need Only Show "Direct and Proximate" Harm as a Result of a Defendant's Crime. 5

C. Emotional or Psychological Harm is Sufficient Harm to Trigger CVRA "Victim" Status

D. Exposing an Individual to a Risk is Sufficient Harm to Trigger CVRA "Victim" Status

E. The Defendant's Crime Directly and Proximately Harmed Dr. Page.

1. Dr. Page was Harmed by Having the FISC Review a Warrant Application for Surveilling His Communications Based on False Information

2. Dr. Page Was Directly Harmed as a Result of the Defendant's Crime........ 14

3. Dr. Page Was Proximately Harmed as a Result of the Defendant's Crime

II. The Court Should Issue a Published Opinion on the Important and Recurring Issue of How to Determine Whether an Individual is a "Crime Victim" Under the CVRA

CONCLUSION 


\section{TABLE OF AUTHORITIES}

$\underline{\text { Cases }}$

Burrage v. United States,

571 U.S. 204 (2014)

In re de Henriquez,

No. 15-3054, 2015 WL 10692637 (D.C. Cir. 2015)

passim

In re Fisher,

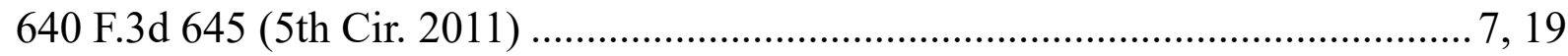

In re McNulty,

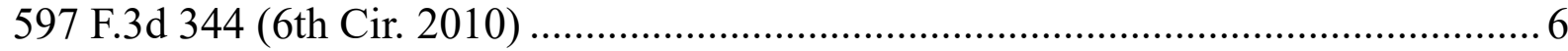

In re Stewart,

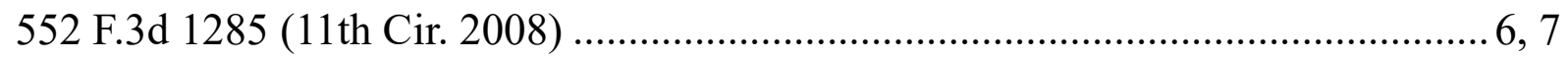

Kendall v. Gore Properties, Inc.,

236 F.2d 673 (D.C. Cir. 1956)

Kenna v. United States Dist. Court for C.D. Cal., 435 F.3d 1011 (9th Cir. 2006) $3,4,5$

Morris v. Nielsen,

374 F. Supp. 3d 239 (E.D.N.Y. 2019) $7,10,15$

United States v. Atl. States Cast Iron Pipe Co., 612 F. Supp. 2 d 453 (D.N.J. 2009)... 4,6

United States v. Degenhardt,

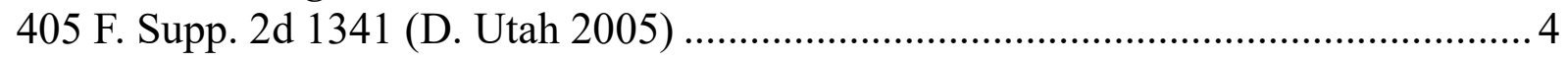

United States v. Donaby, 349 F.3d 1046 (7th Cir. 2003) 14

United States v. Giraldo-Serna, 118 F. Supp. 3d 377 (D.D.C. 2015) mandamus granted in part by In re de Henriquez, 2015 WL 10692637 (D.C. Cir. 2015), on remand, U.S. v. GiraldoSerna, No. 04-114-1-RBW, Dkt. 541 (Mar. 14, 2016) ..... passim

United States v. Hackett,

311 F.3d 989 (9th Cir. 2002) 15 
United States v. Haggard,

41 F.3d 1320 (9th Cir. 1994) ........................................................................... 18, 19

United States v. Monzel,

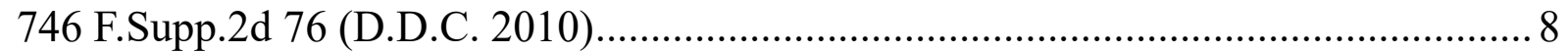

United States v. Stevens, 239 F. Supp. 3d 417 (D. Conn. 2017) …………….............................................. 5

United States v. Turner,

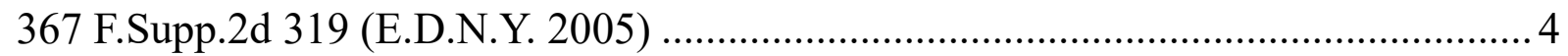

\section{$\underline{\text { Statutes }}$}

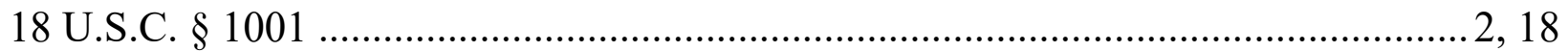

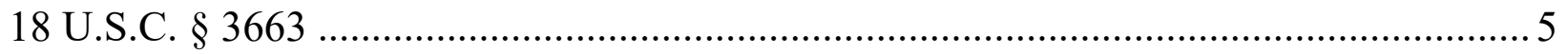

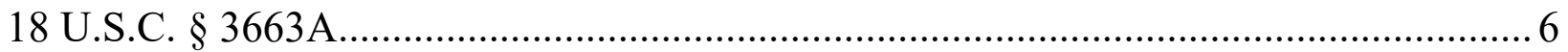

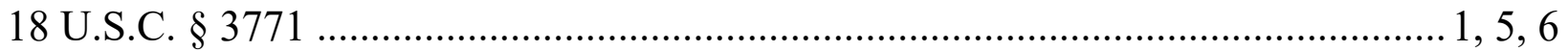

Other

Cassell, Paul G., Recognizing Victims in the Federal Rules of Criminal Procedure:

Proposed Amendments in Light of the Crime Victims' Rights Act,

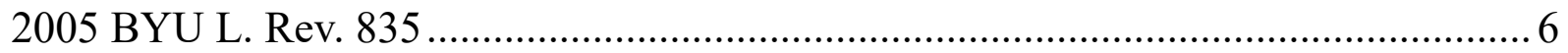

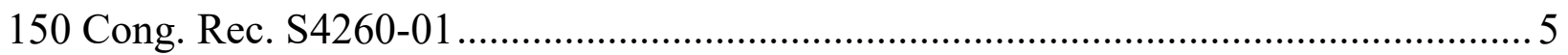

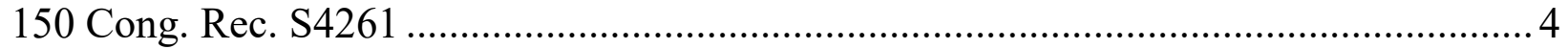

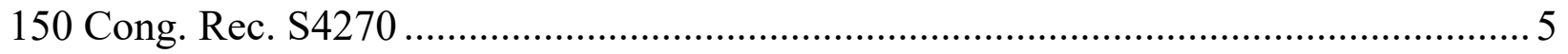

Dressler, Joshua, Understanding Criminal Law (4th ed. 2006) ......................................... 10

Duff, R.A., Criminalizing Endangerment,

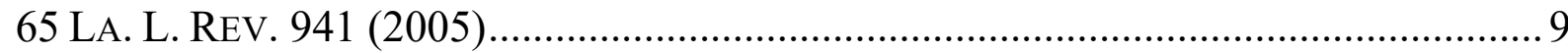

Finkelstein, Claire, Is Risk a Harm?,

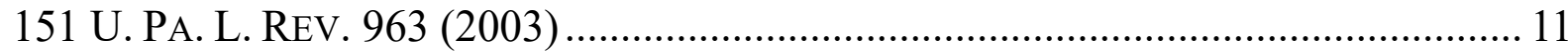

Garvin, Margaret \& Douglas E. Beloof, Crime Victim Agency: Independent Lawyers for Sexual Assault Victims, 13 OHIO ST. J. CRIM. L. 67 (2015) .... 
4 HARPER, JAMES AND GRAY ON TORTS $§ 20.5(6)$ (3d ed. 2007)..................................... 19

Kaplan, John et al., CRIMINAL LAW 293(4th ed. 2000) …................................................ 15

Hon. Jon Kyl, Steven J. Twist \& Stephen Higgins, On the Wings of Their Angels:

The Scott Campbell, Stephanie Roper, Wendy Preston, Louarna Gillis, and Nila Lynn Crime Victims'Rights Act, 9 LEWIS \& CLARK L. REV. 581 (2005) .............................................................. 4, 6

Perkins, Rollin, and Ronald Boyce, CRIMINAL LAW 830 (3d ed. 1982) .............................

PROSSER AND KEETON ON THE LAW OF TORTS $\S 43$ (5th ed. 1984) ................................... 19

Williams, Glanville, TEXTBOOK OF CRIMINAL LAW (1983)............................................. 15

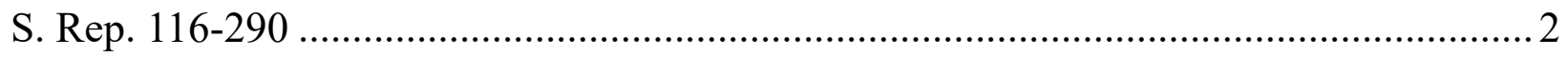


BRIEF OF THE NATIONAL CRIME VICTIM LAW INSTITUTE, THE NATIONAL ORGANIZATION FOR VICTIM ASSISTANCE, THE NATIONAL CENTER FOR VICTIMS OF CRIME, ARIZONA VOICE FOR CRIME VICTIMS, THE NETWORK FOR VICTIM RECOVERY OF THE DISTRICT OF COLUMBIA, OHIO CRIME VICTIM JUSTICE CENTER, ROCKY MOUNTAIN VICTIM LAW CENTER, SOUTH CAROLINA VICTIM ASSISTANCE NETWORK, AND UTAH CRIME VICTIMS LEGAL CLINIC AS AMICI CURIAE IN SUPPORT OF MOTION FOR RELIEF UNDER THE CRIME VICTIMS' RIGHTS ACT

COME NOW the National Crime Victim Law Institute, the National Organization for Victim Assistance, the National Center for Victims of Crime, Arizona Voice for Crime Victims, Network for Victim Recovery of the District of Columbia, Ohio Crime Victim Justice Center, Rocky Mountain Victim Law Center, South Carolina Victim Assistance Network, and Utah Crime Victims' Legal Clinic (hereinafter Amici Crime Victims' Rights Organizations), having previously sought leave to file this brief, to file this brief as amici curiae in support of Dr. Carter Page's Motion for Relief Under the Crime Victims' Rights Act (CVRA) (Dkt. 23-2).

As explained below, Congress enacted the CVRA to provide a comprehensive bill of rights for "crime victims." Congress also provided an expansive definition of who qualifies as a "crime victim," extending protections to any individual who is "directly and proximately harmed" by a federal offense. 18 U.S.C. $\S 3771(\mathrm{e})(2)(\mathrm{a})$. Under this broad definition, any person who is directly and proximately harmed in any way-including suffering dignitary or emotional harm to any degree — is a "victim" under the CVRA. Dr. Page meets this requirement.

This brief addresses only the key legal issue of determining Dr. Page's crime victim status in this particular criminal prosecution. Amici Crime Victims' Organizations are 
aware that the facts surrounding this case have drawn considerable public attention. ${ }^{1}$ In this brief, the Amici do not address any issue apart from the issue currently before the Court: Whether Dr. Page was a "crime victim" of the Defendant's crime under the CVRA. Because Dr. Page was directly and proximately harmed by the Defendant's false statement made in connection with the Government's renewal of a Foreign Intelligence Surveillance Act (FISA) warrant authorizing surveillance of Dr. Page's private communications, Dr. Page is a CVRA "victim." Put more plainly, when a Government official makes a false statement in connection with an application to a federal court to obtain a warrant authorizing a search of a specifically identified person, that crime is not a "victimless" crime. Accordingly, this Court should recognize Dr. Page's CVRA “victim” status.

\section{FACTUAL BACKGROUND}

Amici take no position on any disputed facts in this case. Instead, Amici rely solely on the Statement of Offense in Support of Guilty Plea (Dkt. 9), which the Defendant signed when he pleaded guilty to violating 18 U.S.C. $\S 1001(a)(3)$.

Amici highlight just one crucial fact: Defendant's criminal false statement was used during the Government's FISA warrant renewal application process - a process that renewed a warrant to surreptitiously surveil Dr. Page.

${ }^{1}$ See, e.g., S. Rep. 116-290, Report of the Sen. Select Comm. on Intelligence on Russian Active Measures Campaigns and Interference in the 2016 U.S. Election, Volume 4: Review of the Intelligence Community Assessment, 116th Cong., 1st Sess. (Nov. 20, 2020) (concluding on a bipartisan basis that the initial surveillance of Dr. Page was justified). 


\section{ARGUMENT \\ I. Under the CVRA, Dr. Page is a "Crime Victim" of the Defendant's Offense.}

The Defendant pleaded guilty to knowingly or willfully making false material statements in a matter within the jurisdiction of the judiciary ${ }^{2}$ - specifically, altering an email to make it appear as though Dr. Page had not previously served as a source for a Government agency. The Defendant's criminal false statement then quickly resulted in an application to the Foreign Intelligence Surveillance Court (FISC) to renew a FISA warrant to surveil Dr. Page's private communications - an application the FISC approved without having before it all relevant and accurate information. Thus, Dr. Page was directly and proximately harmed by the Defendant's interference with the proper judicial consideration to which he was entitled, making him a "crime victim" with protected CVRA rights.

\section{A. The CVRA Is a Broad Bill of Rights Protecting All "Victims" of Federal Crimes.}

In 2004, Congress "crafted the CVRA to recognize the harm and anguish suffered by victims of crime." In re de Henriquez, No. 15-3054, 2015 WL 10692637, at *2 (D.C. Cir. 2015). Congress intended to dramatically rework the federal criminal justice system by uprooting the long-held "assumption that crime victims should behave like good Victorian children - seen but not heard." Kenna v. United States Dist. Court for C.D. Cal., 435 F.3d 1011, 1013 (9th Cir. 2006). The "CVRA stemmed from a concern in part that 'prosecutors and law enforcement officers too often ignored or too easily dismissed the

\footnotetext{
${ }^{2}$ In pleading guilty, the Defendant agreed that his criminal false statement "pertained to a matter within ... the jurisdiction of ... the judicial branch of the Government of the United States." See Statement of Offense 17.
} 
legitimate interests of crime victims." United States v. Stevens, 239 F. Supp. 3d 417, 420 (D. Conn. 2017) (quoting United States v. Turner, 367 F.Supp.2d 319, 322 (E.D.N.Y. 2005)). The CVRA is thus best understood as part of a decades-long "civil rights movement" that sought to "end the unjust treatment of crime victims by reforming the culture of the criminal justice system." Hon. Jon Kyl, Steven J. Twist, and Stephen Higgins, On the Wings of Their Angels: The Scott Campbell, Stephanie Roper, Wendy Preston, Louarna Gillis, and Nila Lynn Crime Victims'Rights Act, 9 LEWIS \& CLARK L. REV. 581, $583(2005)$.

Congress designed the CVRA "to be a 'broad and encompassing' statutory victims' bill of rights," United States v. Degenhardt, 405 F. Supp. 2d 1341, 1343 (D. Utah 2005) (quoting 150 CONG. REC. S4261 (Apr. 22, 204) (statement of Sen. Feinstein)), thereby "making victims independent participants in the criminal justice process." Kenna, 435 F.3d at 1013. Congress was concerned that crime victims were "treated as non-participants in a critical event in their lives. They were kept in the dark by . . . a court system that simply did not have a place for them." 150 CONG. REC. S4261 (Apr. 22, 2004) (statement of Sen. Feinstein). To reform the system, Congress gave victims the right "to participate in the process where the information that victims and their families can provide may be material and relevant." Id. The CVRA's objective was thus to give all those affected by crimes valuable rights, including but not limited to the right to be an independent voice in the criminal proceedings that directly implicate them. Id. And the CVRA specifically "places responsibility on the [district] court for its implementation, requiring that 'the court shall ensure that the crime victim is afforded [those] rights." United States v. Atl. States Cast 
Iron Pipe Co., 612 F. Supp. 2d 453, 458 (D.N.J. 2009) (citing 18 U.S.C. § 3771(b)(1)) (emphasis added); see also Stevens, 239 F. Supp. 3d at 421 (explaining that "the CVRA imposes no less than an affirmative obligation on judges to ensure that the victim's rights are respected" (emphasis in original)).

\section{B. To Be Recognized as a "Victim" of a Federal Crime, an Individual Need Only Show "Direct and Proximate" Harm as a Result of a Defendant's Crime.}

As part of its broad and encompassing bill of rights for victims, Congress unsurprisingly crafted a broad definition of the "crime victims" who would be protected. Indeed, the CVRA's congressional co-sponsors described the term "victim" as having "an intentionally broad definition because all victims of crime deserve to have their rights protected.” 150 CONG. REC. S4260-01, S4270 (Apr. 22, 2004) (colloquy between cosponsors Senator Feinstein and Senator Kyl); see also Kenna, 435 F.3d at 1015-16 (discussing significance of CVRA co-sponsors' Senate floor statement).

Under the CVRA, a "crime victim" is "a person directly and proximately harmed as a result of the commission of a Federal offense or an offense in the District of Columbia." 18 U.S.C. $\S 3771(\mathrm{e})(2)(a)$. Congress did not newly mint this language for the CVRA. The "direct and proximate" harm requirement has long existed in federal law, specifically in restitution statutes. For example, the Victim and Witness Protection Act (VWPA) defines a "crime victim" entitled to seek restitution as "[a] person directly and proximately harmed as a result of the commission of an offense for which restitution may be ordered." 18 U.S.C. $\S 3663(a)(2)$ (emphasis added). Similarly, the Mandatory Victims Restitution Act (MVRA) defines a "crime victim" as "[a] person directly and proximately harmed as a result of the 
commission of an offense for which restitution may be ordered." 18 U.S.C. $\S 3663 \mathrm{~A}(\mathrm{a})(2))$ (emphasis added). Thus, in drafting the CVRA, Congress simply borrowed the phrase from these earlier-enacted restitution statutes. See Hon. Jon Kyl et al., supra, 9 LEWIS \& CLARK L. REV. at 594 ("The CVRA's definition of a crime victim is based on the federal restitution statutes.”); Cassell, supra, 2005 BYU L. REV. 835, 857.

Because the definition of "crime victim" contained in the CVRA is essentially identical to the definitions contained in the VWPA and MVRA, courts have often looked to these earlier restitution statutes (and court decisions interpreting them) for guidance in applying the CVRA. See Atlantic States Cast Iron Pipe Co., 612 F. Supp. 2d at 462; see also In re McNulty, 597 F.3d 344, 350 n.6 (6th Cir. 2010) (holding that cases defining "victim" under VWPA and MVRA are "persuasive" but "not binding on our interpretation of the CVRA"); Under this body of restitution law, this Court and others have frequently used a two-part analysis to determine whether a person affected by a crime meets the CVRA's definition of crime victim. Courts examine "(1) the behavior constituting [the] 'commission of a [f]ederal offense'; and (2) 'the direct and proximate effects of that behavior on parties other than the United States."' United States v. Giraldo-Serna, 118 F. Supp. 3d 377, 382-83 (D.D.C. 2015) (quoting In re Stewart, 552 F.3d 1285, 1288 (11th Cir. 2008) (quoting 18 U.S.C. § 3771(e)) (cleaned up), mandamus granted in part by In re de Henriquez, 2015 WL 10692637 (D.C. Cir. 2015); see also In re McNulty, 597 F.3d at 351 ('In making this [CVRA 'victim'] determination, ... [courts] must (1) look to the offense of conviction, based solely on facts reflected in the jury verdict or admitted by the defendant; and then (2) determine, based on those facts, whether any person or persons 
were 'directly and proximately harmed as a result of the commission of that [f]ederal offense."” (internal quotation omitted)); Morris v. Nielsen, 374 F. Supp. 3d 239, 252 (E.D.N.Y. 2019) ("phrase 'direct and proximate' has thus been defined consistently for over a hundred years, in both common and federal statutory law").

An individual qualifies as a victim under the CVRA even when not the target of a crime, so long as that individual is harmed as a result of the crime's commission. As the Eleventh Circuit has explained, a "crime victim" need not even be included in the charging document:

[The CVRA] does not limit the class of crime victims to those whose identity constitutes an element of the offense or who happen to be identified in the charging document. The statute, rather, instructs the district court to look at the offense itself only to determine the harmful effects the offense has on parties. Under the plain language of the statute, a party may qualify as a victim, even though it may not have been the target of the crime, as long as it suffers harm as a result of the crime's commission.

Stewart, 552 F.3d at 1289.

In sum, '[t]he CVRA's 'directly and proximately harmed' language imposes dual requirements of cause in fact and foreseeability. A person is directly harmed by the commission of a federal offense where that offense is a but-for cause of the harm. A person is proximately harmed when the harm is a reasonably foreseeable consequence of the criminal conduct." United States v. Giraldo-Serna, 118 F. Supp. 3d 377, 383 (D.D.C. 2015) (quoting In re Fisher, 640 F.3d 645, 648 (5th Cir. 2011) (internal quotation omitted)), mandamus granted in part by In re de Henriquez, 2015 WL 10692637 (D.C. Cir. 2015). 


\section{Emotional or Psychological Harm is Sufficient Harm to Trigger CVRA "Victim" Status.}

While a movant seeking to establish CVRA victim status must demonstrate "harm" from a defendant's crime, the requisite "harm" can be of any type-including, for example, intangible harms such as emotional distress, affront to dignity, or invasion of privacy. The CVRA's plain language leads directly to the conclusion that sufficient "harm" to establish "victim" status exists whenever an identifiable individual is harmed in any way from a defendant's crime. Congress used the broad term "harm," which is commonly defined as "physical or mental damage: injury" Webster's Third New International Dictionary 1034 (2002) (emphasis added). "Mental damage" or "injury" can broadly include many kinds of impacts on crime victims. For example, an affront to dignity by itself has been found to confer "crime victim" status under the CVRA. See, e.g., United States v. Monzel, 746 F.Supp.2d 76, 84 (D.D.C. 2010) (finding that a defendant's viewing of a child sex abuse image harmed the child depicted). The CVRA nowhere requires additional physical or tangible consequences to follow from the "harm."

If Congress wanted to limit the crime victims protected in the statute to those who were physically or economically injured (i.e., those who suffered tangible physical or economic consequences), it could have easily written such a limitation into the statute. It did not do so. Presumably, the reason is that such a narrow approach would constrict the CVRA to offenses involving direct physical or economic injury-leaving out many other important crimes such as attempted murder, assault, stalking, possession of child pornography, child endangerment, drunk driving, mailing threatening communications, 
lewdness in the presence of a child, discharge of a pollutant, blackmail, and extortion, among countless other offenses. It is hornbook law that criminal law recognizes "harm" when there is an "invasion of any social interest which has been placed under the protection of a criminal sanction (whether by common law or statute)." ROLLIN M. PERKINS \& Ronald N. BOyCE, Criminal LaW 830 (3d ed. 1982). In using the unqualified term "harm" as the CVRA's trigger, Congress protected all persons who are harmed in any way by crimes.

\section{Exposing an Individual to a Risk is Sufficient Harm to Trigger CVRA "Victim" Status.}

Being exposed to risk is also a "harm" to a victim. This conclusion follows naturally from Congress' use of the term "harm," which includes "injury." Webster's Third New International Dictionary 1034 (2002). As one legal scholar has explained, "We have an interest in being safe - in being securely free of the risk of substantive harm; that interest is set back when I am endangered, even if no substantive harm ensues." R.A. Duff, Criminalizing Endangerment, 65 LA. L. REV. 941, 949 (2005).

As one example, consider a prosecution for attempted murder under 18 U.S.C. $\S$ 1113. If a defendant with intent to kill shoots a bullet at a person's head, the fact that the bullet whistles past the person's ear rather than striking and killing the target would, on a constricted reading of the CVRA, mean that no victim suffered a "harm" and thus the CVRA would be inapplicable. Under such a reading, attempted murder would oddly be rendered a "victimless" crime because the target faced only the risk of death, instead of 
injury or death itself. Yet in this attempted murder example, the shooter has placed his target in jeopardy, creating "victim" status.

In addition, it makes no difference whether the target was aware that the bullet was fired at him. A victim need not even be present to a "victim" under the CVRA. Morris v. Nielsen, 374 F. Supp. 3d 239, 254 (E.D.N.Y. 2019) ("Under the CVRA and the MVRA, a victim need not have been physically present at the commission of the crime."). Continuing the example from above, a person is a "victim" of an attempted murder even if he is sleeping when the bullet is fired-and even if he continues to sleep after the attack. See Joshua Dressler, Understanding CRIMINAL LAW 122 (4th ed. 2006) (discussing example of sleeping attempted murder victim). Nothing in the CVRA's text indicates that Congress intended for the uninjured target of an attempted murder to be denied victim status simply because of the mere fortuity of the criminal's bad aim with his gun or his stealth in launching the attack. At a minimum, the target of an attempted murder suffers an invasion of his right to personal security, thereby suffering harm. See id. at 122 (“" [S]ocial harm' may be defined as the negation, endangering, or destruction of an individual, group, or state interest which was deemed socially valuable. Thus, the $\ldots$ attempted murderer of the sleeping party [has] endangered the interests of others and [has] caused 'social harm' under this definition") (internal quotation omitted). Indeed, a whole host of offenses commonly thought to be covered by the Crime Victims' Rights Act rests on this reasoning. For example, an assault victim who has had a knife waved in his face has not suffered direct physical injury but surely still qualifies for protection under the Act because of the psychic toll and invasion of the sense of security that such a crime entails. 
In sum, as one scholar has explained, all persons "have a legitimate interest in avoiding unwanted risks. A [defendant] who inflicts a risk of harm on another damages that interest, thus lowering the victim's baseline welfare." Claire Finkelstein, Is Risk a Harm?, 151 U. PA. L. REV. 963, 964 (2003) (answering "yes" to the question posed in the title). Thus, as relevant to this case, being unjustifiably and criminally exposed to even a risk of having one's private communications improperly surveilled is a harm.

\section{E. The Defendant's Crime Directly and Proximately Harmed Dr. Page.}

In light of the foregoing principles, it is clear that Dr. Page was both "directly" and "proximately" harmed by the Defendant's crime. This section first demonstrates that the "harm" Dr. Page suffered was a subverted FISA warrant application process in which the FISC relied on the Defendant's false statement targeting Dr. Page. This section then demonstrates that the Defendant's crime resulted in Dr. Page suffering this harm both directly and proximately.

\section{Dr. Page was Harmed by Having the FISC Review a Warrant Application for Surveilling His Communications Based on False Information.}

Before turning to the issue of whether the Dr. Page suffered harm directly and proximately, it is useful to understand all the "harms" Dr. Page suffered. One set of harms rests on the consequences from the FISC's renewal of the warrant. As Dr. Page's motion explains, because of the Defendant's false statement, Dr. Page's "true status as a U.S. Government source was not disclosed to the FISC in the 4th [warrant] application, and the 4th FISA warrant was approved. As a result, Dr. Page's communications were surreptitiously surveilled for another three months." Dr. Page Victim Mot. at 5. This chain 
of events - from the Defendant's crime to resulting unjustified secret surveillance invading Dr. Page's privacy—readily establishes harm. As explained above, the CVRA broadly describes the harms that can trigger CVRA victim status. Having one's communications improperly surveilled for months is obviously an invasion of privacy that is harmful.

But this Court need not explore the connection between the Defendant's false statement and the ultimate harmful ramifications to Dr. Page from the FISC's renewal of the warrant. Instead, Amici Crime Victims' Rights Organizations suggest this Court can conclude that Dr. Page is a victim of the Defendant's crime by a simpler route-one focusing on how the Defendant subverted the FISA process.

In the Statement of Offense in Support of Guilty Plea (DE 9), the Defendant admits that his false statement fell within the jurisdiction of the judiciary because it involved an application to renew a FISA warrant to surveil Dr. Page. Statement of Offense qף 8-10. The Defendant also admits that he knowingly provided "materially false" information about the contents of an email from a government agency to his supervisor who prepared the FISA warrant application-materially false information that was important in how the Government crafted its application. Id. at 9 16-17. And the Defendant knew that the substance of the materially false statement he sent to his supervisor about Dr. Page would be conveyed "to the court"-i.e., to the FISC. Id. at $9 \uparrow 10,16$.

Standing alone, these undisputed events establish Dr. Page's "victim" status under the CVRA. The reason that the FISC exists is to make a fair determination of whether to allow Government surveillance of identifiable individuals based on all pertinent evidence. As the FISC explained when learning about the Defendant's deception, "Congress 
intended the pre-surveillance judicial warrant procedure' under FISA, 'and particularly the judge's probable cause findings, to provide an external check on executive branch decisions to conduct surveillance' in order 'to protect the fourth amendment rights of U.S. persons."' In re Accuracy Concerns Regarding FBI Matters Submitted to the FISC, Dkt. No. Misc. 19-02, Order at 2 (Dec. 17, 2019) (quoting Dkt. No. [Redacted], Order and Mem. Op. issued on Apr. 3, 2007, at 14) (emphasis added). Of course, the judiciary cannot "protect the fourth amendment rights of U.S. persons" — such as Dr. Page—when a Government attorney responsible for preparing a FISA application knowingly falsifies material information used in preparing that application.

The Defendant also violated "the heightened duties of probity and transparency that apply in ex parte proceedings." In re Accuracy Concerns Regarding FBI Matters Submitted to the FISC, No. 19-02, Corrected Op. and Order at 2 (FISC Mar. 5, 2020). Because FISC review of warrant applications necessarily takes place without the participation of the individuals being surveilled, Government attorneys involved in FISA applications have special obligations to protect the interests of those individuals. Indeed, "[w]ithout facts that are both accurate and complete, the [FISC] is necessarily hamstrung in its ability to balance the interests of national security with those of personal privacy." Id. at 8 . It is "only when the government fully and accurately provides all information in its possession that is material to whether probable cause exists can the Court's review effectively serve as a check on Executive Branch decisions to conduct surveillance." Id. By committing his crime, the Defendant deprived Dr. Page of the careful FISC review to which he was entitled-i.e., a review of the warrant application based on a full and accurate accounting 
of the available information. Because the Defendant criminally interfered with a fair review of a FISA warrant application targeting Dr. Page, the Defendant harmed Dr. Page. Nothing more is required to establish Dr. Page's "victim" status.

It makes no difference to this conclusion that Dr. Page was unaware of the Defendant's crime when the Defendant committed it. ${ }^{3}$ As described above, an attempt to murder a sleeping victim is no less a crime because the victim was unaware of the attempt. The would-be murderer commits his crime when he sends a bullet whistling pass the ear of his chosen victim, regardless of whether the victim ever becomes aware of it. Here, when the Defendant knowingly launched a false statement to the FISC inculpating Dr. Page, the Defendant destroyed the integrity and accuracy of the FISA process - thereby victimizing Dr. Page by creating a risk that the FISC might improperly authorize surveillance based on falsified information.

\section{Dr. Page Was Directly Harmed as a Result of the Defendant's Crime.}

With this harm to Dr. Page in mind, it also becomes clear that he was "directly" harmed by the Defendant's false statement. A determination of "direct" harm requires applying "the traditional 'but-for' ... cause analysis." United States v. Giraldo-Serna, 118 F. Supp. 3d 377, 382 (D.D.C. 2015), mandamus granted in part by In re de Henriquez, 2015 WL 10692637 (D.C. Cir. 2015). Under traditional but-for cause analysis, this Court must ask whether Dr. Page would have suffered the harm "but for" the defendant's crime. See, e.g., United States v. Donaby, 349 F.3d 1046, 1054 (7th Cir. 2003) (interpreting "direct

\footnotetext{
${ }^{3}$ Of course, Dr. Page has since learned of the Defendant's crime and was harmed at that time. This is an additional reason for concluding he is a victim of the Defendant's crime.
} 
and proximate harm" language in the MVRA, the district court properly found that a police department was entitled to restitution as a victim because "but for the [defendant's] robbery," the department's car would not have been damaged during the ensuing chase).

But-for causation can be construed exceptionally broadly. See, e.g., JOHN KAPLAN ET AL., CASES AND Materials In CRIMINAL LAW 293(4th ed. 2000) ("the notion of butfor causation is ridiculously wide, because it takes us back to Adam and Eve.") (quoting GLANVILLE WiLLIAMS, TEXTBOOK OF CRIMINAL LAW 379-80 (1983)). In this case, without exploring the furthest reaches of but-for causation, this Court can easily find that, because the Defendant's crime directly deprived Dr. Page of a fair process through which the FISC would determine whether his private communications would be surveilled, Dr. Page was directly harmed. Put more simply, but-for the Defendant's crime, Dr. Page would not have been criminally deprived of the fairness in the FISC process to which he was entitled.

In assessing but-for causation, it is important to understand that the CVRA does not impose on a victim the extraordinary task of establishing that a defendant's crime was somehow the sole cause of the victim's harm. In identifying who is a "victim" of a crime, "[c]ourts generally agree that there can be multiple causal steps connecting the criminal act to the victim." Morris v. Nielsen, 374 F. Supp. 3d 239, 254 (E.D.N.Y. 2019); see United States v. Hackett, 311 F.3d 989, 993 (9th Cir. 2002) (upholding restitution award to "victim" because "[a]lthough there are multiple links in the causal chain, the district court did not err by finding that [the defendant's] conduct [in aiding and abetting the manufacture of methamphetamine] was directly related to the cause of the fire."). This point is well illustrated by the D.C. Circuit's reversal of a decision from this Court denying "crime 
victim" status to family members of an individual who had been murdered by a Columbian drug conspiracy. See United States v. Giraldo-Serna, 118 F. Supp. 3d 377, 382 (D.D.C. 2015), mandamus granted in part by In re de Henriquez, 2015 WL 10692637 (D.C. Cir. 2015). This Court had denied "victim" status to the family of Julio Henríquez, an anti-drug cartel crusader killed in Columbia, reasoning that Henríquez's murder may have stemmed from multiple causes apart from crimes of the drug conspirator being prosecuted before the Court. 118 F. Supp. 3d at 382. In granting mandamus, the D.C. Circuit first concluded that this Court had erred in examining only the conspiracy indictment and statement of facts contained in the resulting plea agreement. 2015 WL 10692637 at *1. The Circuit noted that "because victim status can be argued for even prior to the filing of an indictment, it is clear that Congress intended courts to look beyond the four corners of an indictment or plea agreement" to determine victim status. Id. Thus, in the context of the drug conspiracy in that case, "logic allows for the inference — and Colombian court materials support—-that [the defendant's] paramilitary organization - which relied on 'war taxes' to fund its operations and troops to control the region's coca growth-employed violence and force as part of its method of operation." Id.

The D.C. Circuit next squarely rejected the idea that a victim invoking the CVRA must establish that a defendant's crime was the "sole cause" of harm to a victim. The Circuit explained that "[w]hile it is true that there might have been more than a single cause contributing to the murder of Julio Henríquez, it is also true that a 'but-for' cause of the murder could have been Henríquez's leadership of an organization dedicated to ending the production of coca within the region under the drug conspiracy's direct control." Id. 
(citing Burrage v. United States, 571 U.S. 204, 211-12 (2014)). Thus, the D.C. Circuit expressly recognized that even where various causes might be at play, a defendant's crime could still directly harm a victim: "That there could be a multiplicity of possible 'but-for' causes does not mean that the drug conspiracy fails to qualify as a 'but-for' cause." Id.

Finally, the D.C. Circuit held that a victim invoking the CVRA need not demonstrate "direct traceability" between a defendant's crime and subsequent harm, explaining that "direct traceability between, say, the importation of a single coca plant and the eventual murder of Henríquez is a prohibitively onerous burden.” Id. at *2.

On remand, applying the D.C. Circuit's guidance about the CVRA's wide reach, this Court reconsidered its earlier ruling and concluded that the Henríquez family members were CVRA victims. See Order at 1, U.S. v. Giraldo-Serna, No. 04-114-1-RBW, Dkt. 541 (Mar. 14, 2016) ("It is hereby ordered that the Motion to Enforce Rights Under the Crime Victims' Rights Act by Zulma Natazha Chacin de Henríquez [et al.] ... is GRANTED”). In the Defendant's sentencing memorandum in this case, the only case he cites for denying Dr. Page's victim status is this Court's initial decision rejecting the Henríquez family's motion. See Defendant's Sentencing Memo., Dkt. 21 at 17 n.13. The Defendant fails to recognize the D.C. Circuit's subsequent guidance and this Court's final decision on the issue - which found that CVRA "victim" status existed for the Henríquez family.

Applying these broad principles from the D.C. Circuit to this case, the Defendant's crime directly harmed Dr. Page. While the Defendant's crime may not have been the sole cause of harm to Dr. Page in the FISA process, the Defendant's crime was clearly one direct cause of harm. Specifically, "but for" the Defendant's crime, the FISA application would 
have been quite different—indeed, as the Defendant himself described the situation, it would have been "drastically" different. Statement of Facts at 910 . And in this case, there is clearly a "satisfactory nexus" between the Defendant's crime and Dr. Page's harm. To be sure, after the Defendant sent his falsified email to his supervisor, the supervisor had to prepare the FISA warrant renewal application and submit it to the FISC. But the Defendant bears the "requisite connection" to having harmed Dr. Page by directly providing inaccurate information about Dr. Page's circumstances to an FBI supervisor, knowing that the substance of the information would be then be presented to the FISC.

It is also irrelevant to Dr. Page's "victim" status that it is possible to argue that the Government (either the judicial or the executive branch) was also a "victim" of the Defendant's crime. To be sure, the Defendant made a false statement, in violation of 18 U.S.C. $\S 1001$, that was within the jurisdiction of the judiciary. But in other similar cases, courts have looked to ultimate target of a defendant's false statement crime in determining who was a "victim." For example, in United States v. Haggard, 41 F.3d 1320, 1327 (9th Cir. 1994), a case applying the "vulnerable victim" provision of the sentencing guidelines, a defendant had lied to the FBI and the grand jury about the whereabouts of the body of a homicide victim. The defendant ultimately pleaded guilty to two counts of making false statements in violation of 18 U.S.C. $\S 1001$ and one count of obstructing an FBI investigation in violation of 18 U.S.C. $\S 1505$. In affirming a district court finding that the family of the homicide victim was also a "victim" of the $\S 1001$ crimes, the Ninth Circuit explained that "[t]here were two direct victims of [the defendant's] crimes. Obviously, [the defendant's] action in obstructing justice and lying to the FBI and the grand jury directly 
victimized the federal government. Just as clearly, Haggard directly targeted and victimized [the murder victim's] family." Id. at 1327. So too here. In distorting the FISA process, the defendant clearly targeted and victimized not only Government processes, but also the person most affected by those processes-Dr. Carter Page.

\section{Dr. Page Was Proximately Harmed as a Result of the Defendant's Crime.}

Dr. Page was "proximately harmed" by the Defendant's crime. As this Court has explained, for purposes of the CVRA, a "person is proximately harmed when the harm is a reasonably foreseeable consequence of the criminal conduct." United States v. GiraldoSerna, 118 F. Supp. 3d 377, 383 (D.D.C. 2015) (quoting In re Fisher, 640 F.3d 645, 648 (5th Cir.2011)) (cleaned up).

Under long-settled and standard principles of foreseeability, a "defendant need not have foreseen the precise injury, nor [need] he have had notice of the particular method in which a harm would occur, if the possibility of harm was clear to the ordinarily prudent eye." Kendall v. Gore Properties, Inc., 236 F.2d 673, 682 (D.C. Cir. 1956) (citing Restatement of Torts) (cleaned up). Indeed, there is "universal agreement" in tort law that "what is required to be foreseeable is only the general character or general type of the event or harm and not its precise nature, details, or above all manner of occurrence. See PROSSER AND KEETON ON THE LAW OF TORTS $§ 43$, at 299 (5th ed. 1984); 4 HARPER, JAMES AND GRAY ON TORTS $\S 20.5(6)$, at 203 (3d ed. 2007) ("Foreseeability does not mean that the precise hazard or the exact consequences that were encountered should have been foreseen."). 
Here, the foreseeability of harm by the Defendant to Dr. Page is straightforward. As the Defendant admitted in his Statement of Facts, he "knew that if [Dr. Page] had been a source with [another government agency], that information would need to be disclosed in the FISA renewal process." Statement of Facts 910 . Indeed, Defendant knew that this subject was a key part of the warrant renewal process, because - as he himself admittedif Dr. Page had been a source for another agency, that would have "drastically change[d] the way that we would [have] handle[d] ... [the] FISA application.” Id. at 10.

Against this backdrop, it was easily foreseeable that criminally and materially altering an email on the pivotal subject of Dr. Page's relationship with another government agency would interfere with the FISC's obligation to fairly evaluate the Government's application to continue surveilling Dr. Page's communications. The Defendant was no stranger to the FISA process. To the contrary, the Defendant was an FBI attorney who provided support to the FBI and the National Security Division of the Justice Department (NSD) for the purpose of obtaining FISA warrants. Id. at 9 . The Defendant could clearly foresee harm. The Defendant thus proximately harmed Dr. Page.

\section{The Court Should Issue a Published Opinion on the Important and Recurring Issue of How to Determine Whether an Individual is a "Crime Victim" Under the CVRA.}

In addition to granting Dr. Page's motion, this Court should issue a published decision on this important and recurring issue of when CVRA "victim" status exists. In this case, Dr. Page is represented by experienced legal counsel and Amici Crime Victims' Rights Organizations have been able to timely file this brief elucidating the CVRA's drafting history and meaning. In most other criminal cases, however, putative crime victims 
(unlike criminal defendants) will lack legal counsel. See Margaret Garvin \& Douglas E. Beloof, Crime Victim Agency: Independent Lawyers for Sexual Assault Victims, 13 OHIO ST. J. CRIM. L. 67, 77 (2015). A published decision here will thus not only resolve Dr. Page's pending motion but also provide guidance in future cases for courts, counsel, and crime victims.

\section{CONCLUSION}

This criminal case has been widely discussed across the country, with strongly held and differing views resolutely expressed. This brief, however, is entirely agnostic on any such views and any resulting political ramifications. Instead, this brief takes a more limited — but extremely important—-foundational procedural position. Amici believe that in enacting the CVRA, Congress required this Court to hear from any victim who was harmed by the Defendant's crime, with the definition of "victim" being expansive. And it is precisely because differing views exist about this case that hearing from the victim here is extremely important. If this Court grants Dr. Page the opportunity to provide a victim impact statement before it imposes sentence, then the public will have greater confidence in the case's outcome- - which is one of the reasons why Congress included victims in the criminal justice process by enacting the CVRA.

This Court should grant Dr. Page's motion to be recognized as a "victim" of the Defendant's crime. The Court should publish its decision granting the motion. 
Respectfully submitted,

/s/ James. R. Marsh

James R. Marsh

Paul G. Cassell

(Local Counsel)

(Counsel of Record)

DDC Bar ID 436448

S.J. QUINNEY COLLEGE OF LAW

MARSH LAW FIRM PLLC

University of Utah

31 Hudson Yards, 11th Floor

383 S. University St.

New York, NY 10001

(212) 372-3030

Salt Lake City, UT 84112

jamesmarsh@marsh.law

(801) 585-5202

cassellp@law.utah.edu

(no institutional endorsement implied)

(pro hac vice application to be filed)

Attorneys for Crime Victims' Rights Organizations 


\section{CERTIFICATE OF SERVICE}

I certify that on December 16, 2020, the foregoing document was served on the parties to the proceedings via email.

/s/ James R. Marsh

James R. Marsh 